\title{
STRUCTURAL PATTERNS AND STRATEGIES OF CODESWITCHING IN IGBO-ENGLISH BILINGUAL DISCOURSE
}

\author{
Ihuọma I. Akinrẹmi \\ University of Jos, Nigeria
}

\begin{abstract}
This study identifies and describes the patterns found in Igbo-English codeswitching using a typology of codeswitching proposed in the literature. Two patterns in the three-way typology are identified. In the alternational pattern neither language dominates the other, whilst the insertional pattern involves asymmetry in the roles of the two languages, with Igbo as the matrix language that provides the morphosyntactic structure of the bilingual clause. Certain structural features of the Igbo morphosyntactic frame are identified as evidence of a matrix-embedded language asymmetry. In particular, it is demonstrated that the feature of morphosyntactic integration serves as the diagnostic for identifying the type of codeswitching within a clause and that it effectively distinguishes alternation and insertion, especially in peripheral switching. In the insertional pattern, the Igbo grammatical frame forces morphological integration of inserted English verbs but in the alternational pattern, verbs remain monolingual in the participating languages. The paper concludes that although the two patterns are attested in the Igbo-English language pair, the insertional pattern is dominant.
\end{abstract}

Keywords: codeswitching, discourse analysis, Igbo, morphosyntax

\section{Introduction}

Codeswitching refers to the use of elements belonging to more than one language, consciously or unconsciously, by speakers who have two (or more) languages in their repertoires when speaking with other speakers who are bilingual in the same languages. Codeswitching is attested in the speech of bilinguals all over the world. Codeswitching research has progressed under three main perspectives: the psycholinguistic perspective focuses on the altering of the human internal mechanism as the basis for the coding and decoding of speech in two forms; the sociolinguistic perspective has as emphasis the social and psychological motivations for codeswitching; the grammatical or structural perspective interprets codeswitching as a phenomenon subject to grammatical rules and constraints.

The present study is based on the speech of speakers who are bilingual in English and Igbo, a West Benue-Congo language of south-east Nigeria. Codeswitching among Igbo-English bilinguals is generally associated with educated speakers, especially those of the younger generation. Previous studies on Igbo-English codeswitching have mainly adopted a sociolinguistic perspective, highlighting its functions as a conscious discourse strategy (Nwoye, 2003), the motivations for its use by bilinguals (Obiamalu \& Mbagwu, 2008) and its contribution to the status of Igbo as a "seriously endangered language" (Azuonye, 2003). A grammatical perspective is adopted in Uduma (2010), in which some structural aspects of Igbo-English codeswitching are considered. However, the structural patterns observable in Igbo-English bilingual discourse have not been explored in light of the typology of codeswitching established in the literature. This study 
fills that gap by identifying the structural patterns and strategies of Igbo-English codeswitching within the typology of codeswitching patterns, and outlining the distinguishing features of the patterns.

The rest of the paper is structured as follows: Section 2 reviews the literature on codeswitching and notes the implications of certain assumptions for the Igbo-English language pair. It also defines terms used in the paper. Section 3 presents the methodology of data collection and the theoretical framework adopted in the study. Section 4 and Section 5, respectively, focus on the alternational and insertional patterns of codeswitching in the Igbo-English language pair. Section 6 gives a description of the matrix language in Igbo-English insertional codeswitching by examining structures in which an Igbo clausal frame forces morphological integration of English verbs. Section 7 demonstrates that insertion and alternation can be distinguished in peripheral switching by the criterion of morphological integration, and Section 8 concludes the paper.

\section{Review of Literature on Codeswitching: Implications for the Igbo-English language pair}

Studies on the structure of codeswitching generally distinguish two phenomena in the way bilinguals combine elements of the languages in their repertoire. Sometimes the linguistic units of the two languages are found "across sentence boundaries within the same speech events", and at other times "within the same sentence and speech event" (Bokamba, 1989, p. 278). The following are examples of the two phenomena from Lingala-French codeswitching (Bokamba, 1989, p. 279):

(1) Na-ke-i Kimwenza. Je reviens dans une heure.

'I am gone to Kimwenza. I will return in an hour.'

(2) Mobali na yó a-téléphon-àkò yó deux fois par jour.

'Your husband calls you twice per day.'

In (1) the speaker switches intersententially from Lingala to French, while in (2) material from both languages are found in the same clause. The two phenomena are distinguished by the fact that in (1) the grammatical systems of the languages remain discrete, while in (2) the grammatical systems of the two languages interact.

Various terms have been proposed in the literature to capture the distinction between the two phenomena, the commonest being the use of the term "codeswitching" (or code-switching or code switching) for the phenomenon represented by (1) and "code-mixing" (or code mixing) for the phenomenon represented by (2) (e.g. Bokamba, 1989; Muysken, 2000). However, the use of the two terms in the literature by various authors is far from consistent, and has created much controversy, ambiguity and confusion. Myers-Scotton (1997) uses the term 'codeswitching' for both phenomena, and distinguishes "intersentential" or "inter-CP" codeswitching" (switching between sentences or clauses) and "intrasentential" or "intra-CP" codeswitching (switching within the same sentence or clause). A similar usage is adopted in this study, i.e. "codeswitching" is used as a cover term and the modifiers "intrasentential" and "intersentential" are used to distinguish the two switching phenomena, where necessary,. 
Understandably, intrasentential codeswitching has been the focal point of structural studies of codeswitching. There is a general agreement that codeswitches do not occur randomly in sentences, but there is no generally acceptable account of the general properties of the codeswitching process (Muysken, 2000). Different researchers on the grammatical structure of codeswitching have put forward different accounts of the combination of material from the participating languages. The proposed codeswitching constraints were supposed to account for all codeswitching patterns, but as more codeswitching data became available, the universality of the constraints was brought into question as they were found to be tenable in some language pairs and would not generalize to all others (Bokamba, 1989; Gardner-Chloros \& Edwards, 2004; Muysken, 2000).

One perspective on codeswitching defines it as "the alternation of two languages within a single discourse, sentence or constituent" (Poplack, 1980, p. 583; emphasis mine), or "the juxtaposition of sentences and sentence fragments, each of which is internally consistent with the morphological and syntactic (and optionally phonological) rules of the language of its provenance" (Poplack, 1993, p. 255; emphasis mine). This perspective considers codeswitching and borrowing as distinct phenomena and predicts the morphosyntactic shape of codeswitched and borrowed elements. True codeswitching is said to involve multi-word fragments "which remain morphologically and syntactically unadapted to recipient-language patterns" (Poplack, Sankoff \& Miller, 1988, p. 52), whereas "lone other-language items overwhelmingly surface with the patterns of the language in which they are incorporated [...] evidence that they have been borrowed into that language" (Poplack \& Meechan, 1998, p. 136).

Studies that define codeswitching as juxtaposition or alternation of material from languages (e.g. Poplack \& Meechan, 1998, and other references cited above) note the preponderance of morphosyntactically integrated lone items (usually major-class content words like verbs and nouns) in bilingual discourse, and generally categorize them as nonce or momentary borrowings, i.e. loans that lack phonological integration and dictionary attestation or diffusion within the community. The class of nonce loans was established on the basis of the Free Morpheme Constraint, which states that "codes may be switched after any constituent in discourse provided that constituent is not a bound morpheme" (Poplack, 1980, pp. 585-586). By predicting that codeswitching is only possible between constituents that are not bound morphemes, the Free Morpheme Constraint rules out switches between a bound morpheme of one language and a free morpheme of another, such as English-Spanish '*eat-iendo' ('is eating') (Poplack, 1980, p. 586).

The Free Morpheme Constraint has implications for morphosyntactically integrated English verbs in Igbo-English bilingual discourse. The verb is the only lexical category in Igbo that takes affixes, both derivational and inflectional (Emenanjo, 1978, 2015). The inflectional morphology of verbs described in Emenanjo $(1978,2015)$ recognizes simple and complex verb roots, and affixes. Verbal suffixes include tense-aspect markers such as the indicative/past tense marker $(-r \mathrm{~V})$, the perfective marker (-la-/-le), the negative marker (-ghi/-ghi), and the open vowel suffix found in certain verb forms. Vowel prefixes include the infinitival prefix $(i-/ i-)$, the participial prefix $(a-/ e-)$ and the vowel prefix $(a-/ e-)$ found in certain verb forms when the subject of the clause is a noun or a plural pronoun ${ }^{1}$. The following examples illustrate these morphological features:

${ }^{1}$ For the verbal affixes given in pairs, the particular form of the affix in a sentence is selected on the basis of vowel harmony with the nearest syllable of the verb. 
(3) a. $\begin{array}{lll}\text { O mè-rè } & \text { ya. }^{2} \\ \text { s/he } & \text { do-PAST it }\end{array}$

'S/he did it.'

b. $\mathrm{O}$ mè-tà-rà ya.

s/he do-ES-PAST it

'S/he did it well/succeeded in doing it.'

c. Ngọzi e-me-ta-ghị ya.

Ngọzi PFX-do-ES-NEG it

'Ngọzi did not do it well/did not succeed in doing it.'

d. O me-e-le ya.

s/he do-OVS-PERF it

'S/he has done it.'

e. Ò chọ-ghị i-me ya.

$\mathrm{s} /$ he want-NEG INF-do it

'S/he does not want to do it.'

f. Ọ gà- è-me ya.

s/he FUT- PRT-do it

'S/he will do it.'

In the example (3a), the $-r \mathrm{~V}$ suffix marking the past tense is attached to the simple verb root me ('do'). Note that the vowel of the $-r \mathrm{~V}$ suffix is always similar to the vowel of the adjacent syllable of the verb root. A complex verb me-ta, composed of a simple verb root me and an extensional suffix $-t a$, is illustrated in (3b) and (3c). In (3b), the complex verb is inflected with the past tense marker, and in (3c), with a negative suffix. There is also a vowel prefix on the complex verb in the verb form expressed in (3c) because the subject is a noun (Ngozi). The example (3d) illustrates the inflection of the verb with the perfective suffix after an open vowel suffix. In (3e), the infinitival prefix is attached to the verb me, and in (3f), the future tense marker $g a$ is used with a participial verb form marked by the prefix $a$ - on the verb me.

Igbo-English bilingual data show that lone English verbs are inflected with Igbo tense-aspect and extensional affixes in exactly the same way Igbo verbs would be inflected in those positions. Eze (1998) adopts the nonce borrowing hypothesis and the Free Morpheme Constraint in his analysis of lone English verbs in otherwise Igbo discourse. He classifies lone English verbs in his corpora, such as those in (4) and (5), as nonce borrowings (Eze, 1998, pp. 184, 187).

2 Tone is marked on Igbo material following the practice in Emenanjo $(1978,2015)$ and Williamson (2013), as follows: high tone (and its variant, downstep) is unmarked (e.g. u); low tone is marked with a grave accent on the vowel (e.g. ù). 


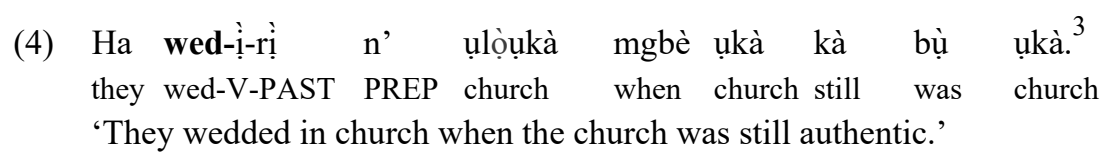

(5) Ọ̀ work-ụ̀-ghị̀.

it work-V-NEG

'It did not work.'

The main criticism of Poplack's position on codeswitching and borrowing has come from Myers-Scotton (1992, 1997). The divergence between Poplack's and Myers-Scotton's positions has dominated the literature on codeswitching constraints and appears to be irresolvable. MyersScotton (1992) does not differentiate between codeswitched and borrowed items on the basis of their morphological shape, and argues that morphosyntactically integrated verbs, such as those in Swahili-English codeswitching (and by implication, Igbo-English bilingual verbs, such as wed-ìrị and work-ùghị in (4) and (5), respectively) are counterexamples to Poplack's (1980) Free Morpheme Constraint (Myers-Scotton (1997, p. 31). Her definition of codeswitching as "the selection by bilinguals or multilinguals of forms from an embedded variety (or varieties) in utterances of a matrix variety during the same conversation" (Myers-Scotton, 1997, p. 3; emphasis mine) is one based on the insertion of elements of one language into an utterance structured in another language. This is a clear departure from the alternation/juxtaposition definition discussed above.

In this regard, Muysken (2000) has noted that elements from participating languages interact in different patterns in different data sets. He claims that the major perspectives on the structure of codeswitching have been shaped by the language pairs studied by different researchers, and proposes a three-way typology for the classification of intrasentential codeswitching patterns into insertion, alternation and congruent lexicalization. Insertion and alternation are the dominant patterns (Backus, 2010; Muysken, 1995). Congruent lexicalization, on the other hand, underlies the study of style shifting and dialect/standard variation rather than bilingual language use proper (Muysken, 2000) and, as such, may not be relevant for the present study. According to Muysken (2000), the three patterns correspond to the main, competing structural approaches to codeswitching, and their occurrence in specific settings is determined by the typological characteristics of the languages involved, as well as psycholinguistic and sociolinguistic factors.

The alternational pattern of codeswitching involves "a true switch from one language to the other, involving both grammar and lexicon" (Muysken, 2000, p. 8), or a process in which the speaker "can best be seen as speaking now one language, now another" (Bentahila \& Davies, 1998 , p. 49). Muysken (2000, p. 8) notes that the alternational pattern of codeswitching is characteristic of "stable bilingual communities with a tradition of language separation." Alternation requires linear equivalence between the participating languages at switch points, in line with Poplack's (1980) Equivalence Constraint, which predicts that when constituents are ordered in the same way in two languages, the boundaries between adjacent fragments within the constituents are favored for codeswitching because the linear order of constituent structure is preserved and lexical material is not omitted or duplicated (Poplack, 2004). This constraint was

3 In Igbo-English bilingual data, Igbo material is in normal font while English material is in bold print. In data quoted from other sources, switching is marked in italics. 
based on the Spanish-English language pair, about which Lipski (1982, p. 198) observes as follows: "English and Spanish share a highly similar syntactic background, both in view of their common Indo-European language heritage and through later common influences. There is often complete syntactic parallelism between an English sentence and its Spanish counterpart." This statement suggests that the alternational pattern would be expected to feature minimally in IgboEnglish codeswitching, as points of linear equivalence between the two languages are far-between.

Muysken (2000) notes that alternational codeswitching may occur clause-centrally at major syntactic boundaries, as illustrated in (6) and (7), or clause-peripherally, as illustrated in (8) and (9):

(6) Bij mijn broer $y$ a un ascenseur en alles.

'At my brother's place, there is an elevator and everything.'

(French-Dutch; Treffers-Daller, 1994, as cited in Muysken, 2000, p. 97)

(7) Je suis au balcon op mijn gemakske zo en train de regarder les étoiles.

'I am on the balcony at my ease thus watching the stars.'

(French-Dutch; Treffers-Daller, 1994, as cited in Muysken, 2000, p. 100)

(8) Si j'avais la maison, maৎamri na : kul temma.

'If I had the house, I would never eat there.'

(Arabic-French; Bentahila \& Davies, 1983, p. 309)

(9) Owóo wa has low market value.

'Our currency has low market value.'

(Yoruba-English; Lamidi, 2009, p. 15)

The second major pattern of codeswitching, insertion, generally involves a situation in which "a single constituent B (with words $b$ from the same language) is inserted into a structure defined by language A, with words $a$ from that language" (Muysken, 2000, p. 7), as illustrated in the following examples:

(10) Anakula plate mbili za murram.

'He eats two plates of maize.'

(Swahili-English; Myers-Scotton, 1997, p. 86)

(11) E wo green dress ko.

'S/he wore a green dress.'

(Adanme-English; Nartey, 1982, p. 87)

The insertional pattern is noted to be frequent in colonial settings and in recent migrant communities, and may also signal asymmetry in speakers' proficiency in the two languages (Muysken, 2000, p. 9). It is noteworthy that much of the African codeswitching data reported in the literature exhibit a dominantly insertional pattern in which a matrix language can clearly be identified (Auer, 1999; Muysken, 2000). Furthermore in codeswitching involving an African language and a European one, the matrix language would usually be the African language, a 
consequence of the sociolinguistic context and the prestige status usually accorded the European languages (Kamwangamalu, 1989b, as cited in Bentahila \& Davies, 1998, p. 30). Ahukanna (1990) observes this pattern as prevalent in Igbo-English codeswitching and views it as a reflection of the dominance-subordination relationship between English and Igbo.

The recognition of asymmetry between the participating languages is a major feature of codeswitching models based on insertion, as exemplified by the Matrix Language Frame model of Myers-Scotton (1997, 1998). The "matrix language" dominates the mixed constituent by providing the morphosyntactic frame within the maximal syntactic category of the clause (S-bar or Complementizer Clause, CP) into which elements of the "embedded language", ranging from single lexical items to multi-word constituents, are inserted.

Another major feature of the insertional pattern of codeswitching is morphosyntactic integration, especially of verbs (Muysken (2000). Bokamba (1989) notes this fact for LingalaFrench, and Myers-Scotton (1997), for Swahili-English codeswitching. They cite examples of verbs of the embedded language (French and English) exhibiting the inflectional morphological characteristics of verbs of the matrix language (Lingala and Swahili).

The data for this study show that both the alternational and insertional patterns of codeswitching are observable in Igbo-English bilingual discourse. The distinguishing features of the two patterns in the language pair will be identified and described in latter sections.

\section{Methodology, Data and Theoretical Framework}

Two sets of codeswitching data are utilized in the study, namely data from participant observation and focus group discussion. Participant observation data were collected from the spontaneous speech of several Igbo-English bilinguals living in Jos, Central Nigeria, within a period of approximately four years. The participants were engaged in a variety of activities in several settings, including the family, the workplace, the market, public transport and other public places. They represented a variety of social backgrounds and educational levels, but were all bilingual in Igbo and English. A cell phone was used to transcribe codeswitched expressions as soon as they were uttered.

The focus group discussions served to supplement the participant observation data. The group consisted of eight members aged between 23 and 55. Four of the participants had secondary level education, and four, tertiary level education. They were recorded in four sessions that lasted approximately six hours in all. In order to minimize the effect of the observer's paradox in the focus group data, the discussions were audio-recorded within contexts that approximated ordinary conversations (Baugh, 1993). Firstly, the research assistant who obtained the data was perceived by the participants as an in-group member and his linguistic repertoire featured the phenomenon under investigation (Poplack, 1993), namely, codeswitching. This created a natural atmosphere and ensured participant rapport. In addition, the participants were recorded in their community while chatting with friends with whom they felt comfortable to use their usual languages of communication and to engage in codeswitching. Secondly, the elicitation technique employed in the interviews was in the form of regular in-group conversation on matters of interest within the community and the society at large. The conversations were loosely moderated by the research assistant, who introduced discussions on current social events and occurrences at certain points. 
The focus group discussions were recorded with the permission of the participants. They were initially conscious of being recorded, but they generally ignored the recording equipment as the conversation progressed, and codeswitching occurred as unconscious language behavior. The recorded conversations were later transcribed, and the transcripts were classified and analyzed.

The language mixing tokens recorded in the data were tagged and classified. Instances of intrasentential and intersentential switching/mixing were identified, and it was also necessary to decide which of the tokens constituted true codeswitching, and which, other phenomena, particularly borrowing. Following Bentahila and Davies (1983), Kamwangamalu (1992) and Myers-Scotton $(1992,1997,2006)$, the study adopts the assumption that whereas a borrowed form can be predicted to reoccur in the recipient language, a codeswitched form has no predictive value or shows no frequency of occurrence in a data corpus or in a speech community. The tokens that were classified as true codeswitching were subjected to structural analysis, with the aim of identifying the patterns of Igbo-English codeswitching.

Other data are from published works, which have been duly referenced. Hypothetical data are indicated as such. A few (monolingual) Igbo examples were provided by the author, who is an Igbo-English bilingual.

The study adopts the theoretical framework of the Matrix Language Frame (MLF) (MyersScotton (1992, 1997, 1998, 2002), which proposes a number of related principles to account for contact phenomena, including codeswitching. The basic claims of the MLF are based on the notion of asymmetry. The model claims that every CP (monolingual or bilingual) has a morphosyntactic frame, known as the Matrix Language (the Matrix Language Principle). In codeswitching, asymmetry marks the contributory roles of the participating languages, such that only one of the languages is the (source of the) Matrix Language of a bilingual CP or mixed constituent (the Asymmetry Principle for Bilingual Frames). Similarly, the Uniform Structure Principle, within the context of codeswitching, refers to "the general notion that the basic syntactic frame of the Matrix Language, with its requisite requirements at the level of morphological realization patterns, must be observed in bilingual CPs in classical codeswitching" (MyersScotton, 2002, pp. 108-109).

The MLF also proposes that asymmetry is observed at the morpheme level. This is captured in the distinction made between content morphemes and system morphemes and the claim that "all the morphemes from the participating varieties do not have equal possibilities of occurrence" (Myers-Scotton, 2002, p. 9) (the Morpheme-Sorting Principle). In bilingual or mixed constituents, the Matrix Language provides the word order and is the source of system morphemes, i.e. function words and inflections (the System Morpheme Principle). Only content morphemes can come from the other participating language - the Embedded Language - in mixed constituents. The MLF recognizes three structurally different types of constituent. Two constituent types - the Matrix Language island and the Embedded Language island - are made up entirely of elements of one language and are well-formed according to the grammars of the respective languages. In addition, Embedded Language islands are inserted into a Matrix Language frame. The third type of constituent - the mixed constituent or "Matrix Language + Embedded Language" constituent consists of elements from both languages and is well formed according to the grammar of the Matrix Language. The three types of constituent are illustrated in the following Swahili-English example (Myers-Scotton, 2002, p. 57): 
(12) [Lakini a-na so many problems mtu [a-me- repeat mara ny-ingi $\left.]_{\mathrm{CP}}\right]_{\mathrm{CP}}$ but 3s-with so many problems person 3s-PERF- repeat time CL9-many 'But he has so many problems, [that] [he is] a person [who] has repeated many times.'

There are two CPs in the bilingual sentence (12), as indicated with square bracketing. The first CP contains the Embedded Language island so many problems. In the second $\mathrm{CP}$, the expression $a$ me-repeat is a mixed constituent, while mara nyingi is a Matrix Language island. The claim that the morphologically integrated lone English verb a-me-repeat constitutes a mixed constituent (Myers-Scotton, 2002, p. 58) is at variance with the claim that such elements are instances of nonce borrowing (e.g. Poplack \& Meechan, 1998; Eze, 1998). The general claim of the MLF is that elements of the Embedded Language are "basically morphologically integrated into the Matrix Language" (Myers-Scotton, 2002, p. 108), which agrees with the claim that morphological integration, particularly of verbs, is a diagnostic feature of the insertional pattern of codeswitching (Muysken, 2000). The implication of this for the present study is that morphosyntactically integrated verbal forms in the Igbo-English data are assumed to constitute true codeswitching.

The MLF is adopted as the theoretical framework of this study as it seems to find much relevance in explaining the structure of Igbo-English codeswitching. The study also incorporates two important assumptions; firstly, there are a number of processes at work in codeswitching, which yield different structural patterns, basically, alternation and insertion (Backus, 2010; Muysken, 2000) and, secondly, elements from two languages may be combined in various patterns in the same data set, although one pattern would usually dominate (Deuchar, Muysken \& Wang, 2007).

\section{The Alternational Pattern in Igbo-English Codeswitching}

In Igbo-English bilingual discourse, alternation is observed in intersentential codeswitching, as in the following examples:

(13) Otu à kà ọ dị ebe niile. What I am

manner this that it be place all. What I am

advising is that you have to go back to him.

advising is that you have to go back to him

'That is the way it is everywhere. What I am advising is that you have to go back to him.'

(14) Hapụ̀-nụ-nụ ànyị. Why use us to cast the votes?

leave-ES-PL us why use us to cast the votes

'Just leave us alone. Why use us to cast the votes?'

(15) A-nà ì à-chọpụ̀ta nà $o$ sì ndị

VOC-PROG I PRT-find out that it start those

na- a-chị anyị n'aka. Hope you understand?

PROG PRT-lead us PREP-hand hope you understand

'I've found out that it is the fault of our leaders. Hope you understand?' 
In (13) through (15), the speaker switches intersententially from Igbo to English and the grammatical systems of the participating languages remain discrete, as exemplified by verbs that are monolingual in Igbo (dì = 'be'; hapụnụnụ = '(just) leave alone'; àchopụta = 'finding out'; sì = 'start from'; achi = 'ruling'), and in English ('am advising'; 'go back'; 'use'; 'cast', 'understand').

Intrasententially, alternation occurs in Igbo-English bilingual discourse at points of linear equivalence between the two languages. In such switching the speaker may begin with Igbo and switch to English, as in (16) through (19):

(16) E-nwè-rè $m$ strong belief that we'll make it.

VOC-have-IND I strong belief that we'll make it

'I have strong belief that we'll make it.'

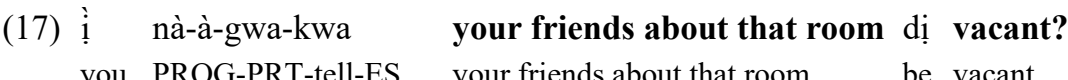

'Have you been telling your friends about that vacant room?'

(18) Ò̀ dị-ghị happy about all these things.

s/he be-NEG happy about all these things

'S/he is not happy about all these things.'

(19) Ọ̀ sịrọ $m$ bịa but I will go and see him.

He say-NEG I come but I will go and see him

'He did not say I should come, but I will go and see him.'

The reverse pattern of alternational switching, i.e. from English to Igbo is also observed, as in (20) through (22):

(20) Those people write-rị $\mathrm{m}, \quad$ sị $m$ that there is no problem.

those people write-PAST me tell me that there is no problem

'Those people wrote me (and) told me that there is no problem.'

(21) I was trying to call you to find out mà ọ bịa-la.

I was trying to call you to find out if he come-PERF

'I was trying to call you to find out if he has come.'

(22) That child will eventually prove you wrong because ọ ga- à-ga gụọ-rọ

That child will eventually prove you wrong because $\quad$ s/he $\quad$ FUT- PRT-go read-BNF

gị akwụkwọ wèta-ra gị certificates.

you book bring-BNF you certificates.

'That child will eventually prove you wrong because s/he will go and study and bring you certificates.'

The examples (16) through (19) and (20) through (22) reveal that structural islands (in the form of clauses and phrases) dominate intrasentential alternational switching, although mixed/bilingual constituents also occur, as in (20) and (22). 


\section{The Insertional Pattern in Igbo-English Codeswitching}

Igbo-English insertional codeswitching involves the insertion of lone English items or multi-word expressions into an Igbo clausal structure. The reverse situation of Igbo elements inserted into an English structure is not attested in the data. The following examples illustrate the insertion of nonverbal English elements into otherwise Igbo discourse:

(23)

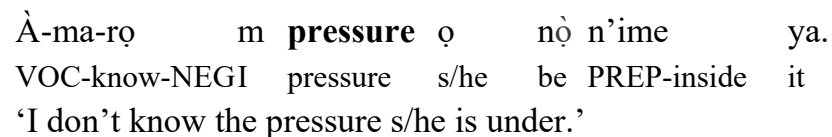

$\begin{array}{lllll}\text { Onye } & \text { ahụ̀ } & \text { a-dị-rọ } & \text { qualified ị-gụ } & \text { ya. } \\ \text { person } & \text { that } & \text { PFX-be-NEG } & \text { qualified } & \text { INF-read }\end{array}$

'That person is not qualified to read it.'

(25) Ì chè nà ndị bi nà those hot areas gà- a-pụ̀ta?

you think that those live PREP those hot areas FUT PRT-come out

'Do you think that those that live in those hot areas will come out?'

(26) Ò bụ-rọ in the interest of ndị ha nà- à-chị.
It be-NEG in the interest of those they PROG PRT-govern
'It is not in the interest of those they govern.'

The English element in (23) through (26) is a noun, an adjective, a noun phrase, and a prepositional phrase, respectively. The matrix language status of Igbo is evident in the examples, i.e. the Igbo language supplies the word order and is the source of the morphosyntactic structure of the CPs into which the English elements are inserted. All the inserted constituents are Embedded Language islands - the morphemes are all from English and the expressions are well-formed according to the grammar of English.

Lone English verbs and verb phrases are also inserted into an Igbo morphosyntactic frame. Igbo verb roots usually end with an open syllable ${ }^{4}$. Consequently, speakers sometimes add an epenthetic vowel to consonant-final English verbs in bilingual discourse. The epenthetic vowel has no morphosyntactic significance; it is used to satisfy the syllable structure requirement of the matrix language. A similar observation is made, in the context of codeswitching, for Swahili verbs (Myers-Scotton, 2002) and Finnish nouns (Poplack, Wheeler \& Westwood, 1989). The following examples illustrate Igbo-English insertional codeswitching involving lone English verbs:

(27) Kèdu provision o make-ì-rì màkà ndị ǹke ọzọ?
what provision s/he make-V-PAST for people of other
'What provision did s/he make for the other people?'

\footnotetext{
4 Igbo has three syllable structures, V, CV and N (Emenanjo, 1978). Simple verbs are monosyllabic with a $\mathrm{CV}$ structure, and complex verbs also end in open syllables. There are no consonant clusters in Igbo and epenthetic vowels are sometimes used by bilinguals to break English consonant clusters (Emenanjo, 2015).
} 
(28) $\mathrm{O}$ disappoint- ị-r-ị $\mathrm{m}$.

$\mathrm{s} /$ he disappoint-V-PAST me

'S/he disappointed me.'

(29) $O$ register-rà $m$ for the exams.

$\mathrm{s} /$ he register-PAST me for the exams

'S/he registered me for the exams.'

(30) How are you sure nà ọ gà- à-work-ụ??

how are you sure that it FUT- PRT-work-V

'How are you sure that it will work?'

(31) Ò nwe-ghi ego i-send-ì ụmụ ya òbòdò oyìbo.

he have-NEG money INF-send-V children his country foreign

'He does not have money to send his children to a foreign country.'

The fact that the Igbo verbal category has an elaborate inflectional system in comparison with other lexical categories, which generally lack inflection in Igbo, is reflected in the Igbo inflectional elements found on the English verbs in (27) through (31) (cf. (23) - (26) above, in which other categories are illustrated). The verbal elements 'make-ì-rì', 'disappoint-ị-rị', 'register-rà', 'àwork-ụ̀', and 'i-send-ì' in (27), (28), (29), (30) and (31), respectively, are mixed constituents in MLF terms, made up of morphemes from the two participating languages. The Matrix Language is the source of the system (inflectional) morphemes. The insertion of lone English verbs into an Igbo morphosyntactic frame yields morphologically integrated or bilingual verbs in all the examples. The Embedded Language (English) verbs are inflected with system morphemes from the Matrix Language (Igbo) - the past tense marker in (27) through (29), the participial prefix in (30) and the infinitival prefix in (31).

Morphosyntactic integration is also realised in insertional codeswitching involving multi-word English verbal expressions. In the following examples, the verb send is inserted into Igbo discourse in a variety of segment types, but with full integration in all instances:

(32) Ọ gà- è-send-ì nwa ya i-nye gị the money.

he FUT- PRT-send-V child his INF-give youthe money

'He will send his child to give you the money.'

(33) Kà m send-ì-e to Mrs. A.

let me send-V-OVS to Mrs. A.

'Let me send to Mrs. A.'

(34) Ọ̀ dị-kwà necessary i-send-ì-rì gị that thing?

It be-ES necessary INF-send-V-BNF you that thing

'Is it still necessary to send you that thing?'

In (32) the English verb send has been inserted as a lone element into an Igbo clausal frame. Lone English verbs nested in an Igbo grammatical frame are, without exception, morphosyntactically 
integrated into Igbo. In (33) send is inserted with a particle to, while in (34), it is inserted with its direct object that thing, although the indirect object (expressed in Igbo) intervenes between the verb and its direct object, an order of constituents shared by both languages. The examples (33) and (34) illustrate the fact that inserted multi-word English verbal segments may be set collocations (including phrasal verbs), as further illustrated in (35) and (36), or expressions consisting of a verb and a constituent in its subcategorization frame, such as its direct object, as further illustrated in (37) and (38). The English verbal expressions are well-formed according to English grammar but the inflectional system of the matrix language forces the integration of the verbs, thereby producing mixed constituents.

The following examples further illustrate the insertion of multi-word English verbal segments into an Igbo morphosyntactic frame.

(35) Mgbè ọ nà- è-pick-ì up bụ̀ mgbè ànyị nọ̀ nà slope. when it PROG-PRT-pick-V up be when we be PREP slope

'It picks up when we are on a slope.'

(36) Ha gà- e-reduce-u ya to nothing.

They FUT- PRT-reduce-V him to nothing

'They will reduce him to nothing.'

(37) OQ nà- è-lead church nà be fa.

he PROG-PRT-lead church PREP place their

'He leads the church in their place.'

(38) January, February, m na- a-bàta, ̀̀ publish-ì-e another one.

January, February, I PROG- PRT-return I publish-V-OVS another one

'In January or February when I return, I (will) publish another one.'

The examples in (35) and (36) contain the fixed expressions pick up and reduce to nothing. In (37) and (38), the verbs lead and publish select the objects church and another one, respectively. In (37), the absence of a determiner before church suggests an overall Igbo grammatical structure in the sentence, owing to the fact that Igbo lacks articles within its class of determiners (Emenanjo, 1978). Morphosyntactic integration is observable on the English verbs in all the examples; the grammatical frame is in Igbo and the inflectional affixes simply attach to the English verbs, resulting in full morphological integration. The English verbs are inflected with Igbo affixes in the same manner and to the same extent as Igbo verbs in similar positions.

\section{The Matrix Language and Morphosyntactic Integration in Igbo-English Codeswitching}

The insertion of lone or multi-word English verbal expressions into the verbal slot when the Matrix Language that provides the morphosyntactic frame, and consequently the inflectional system morphemes, is Igbo generally results in the morphosyntactic integration of English verbs in mixed/bilingual constituents. Verbal integration may be considered as the distinguishing feature of Igbo-English insertional codeswitching. This fact becomes evident when specific features and 
structures of the Igbo morphosyntactic frame are examined. The following sections describe some features and structures of the Igbo matrix language that produce morphosyntactic integration.

6.1. Subcategorization Restrictions. The integration of English verbs often results from the subcategorization requirements of Igbo grammar. The Igbo predicate consists of a verb followed by modifiers such as indirect object, direct object (complement), prepositional phrase and bound cognate noun/bound verb complement (Emenanjo, 1978; Nwachukwu, 1987). The following example illustrates the Igbo verb and its modifiers (Nwachukwu, 1987, p. 8):

(39) Ibe nyè-(r)è-rè m Ogù akwụkwọ enye.
Ibe give-APPL-PAST me Ogu book BCN
'Ibe actually gave the book to Ogu for me/on my behalf.'

The example (39) shows that the applicative object comes immediately after the verb and is followed by the indirect object, the direct object and the bound cognate noun in that order. A prepositional phrase usually comes after all the other verbal modifiers (at the end of the clause) (Emenanjo, 1978). The bound cognate noun as a feature of the Igbo predicate is taken up in a later section. In bilingual discourse, English verbs are inserted into the verbal position in clauses structured according to Igbo grammar. Two constructions will serve as illustrations of the morphosyntactic integration of such inserted verbs.

First, in sentential subject constructions, i.e. verbal expressions occurring in the subject position of a declarative clause, Igbo requires the verbal expression to appear in infinitive form. English has a similar restriction, and gerunds may also be used. In examples (40) and (41), an English (phrasal) verb is inserted in a sentential subject.

(40) [NP I-repair ife n' òbòdo à] can be just as expensive as buying a new one.

INF-repair something PREP town this can be just as expensive as buying a new one.

'To repair something in this town can be just as expensive as buying a new one.'

(Nwoye, 2003, p. 372)

(41) [NP I-settle down ebe à] nà- è-si ike.

INF-settle down place this PROG-PRT-be difficult

'To settle down in this place is difficult.'

The bracketed sentential subjects in (40) and (41), respectively, contain morphosyntactically integrated English verbs which result from the subcategorization requirements of the grammatical frame provided by the matrix language, Igbo.

Secondly, the subcategorization frames of Igbo verbs such as kwesi 'ought/be supposed' cho 'want', and kwe 'agree/allow' require the following verb to be in the infinitival form. (The same subcategorization requirement applies to the English equivalents of these Igbo verbs). In (44) through (46), the clausal complements selected by kwesi, cho and kwe contain English infinitival verbs. 
(42) O kwèsị-rị [ [ ị ịraduate this year].

he suppose-IND INF-graduate this year

'He is supposed to graduate this year.'

(43) E kwèsị-rị [CP i-check-ì ya e-check-i].

IMPERS. PN. ought-IND INF-check-V it HRM-check-V

'It ought to be checked.'

(44) $O$ chọ̀-rọ̀ [CP i-dictate-rì $m$ ihe $m$ gà- è-me].

$\mathrm{s} /$ he want-IND INF-dictate-BNF me thing I FUT- PRT-do

'S/he wants to dictate to me what to do.'

(45) Ò̀ chọ-ghị [CP ị-recommend $m$ for that work].

he want-NEG INF-recommend me for that work

'He didn't want to recommend me for that work.' (Ahukanna, 1991, p. 184)

(46) Obì ọ̀ gà- è-kwe-kwa ya [CP ị-continue na- à-kwụ n' anwụ]? heart it FUT- PRT-allow-ES himINF-continue PROG-PRT-stand PREP sun 'Will he have the heart (courage) to continue standing in the sun?'

The bracketed complement clauses of the verbs kwesi, cho and kwe in (42) through (46) are insertions, in line with the observation in Muysken (2000) that the presence of selection may signal insertion or congruent lexicalization. The complement clauses are mixed constituents in which the word order and system morphemes are provided by the matrix language, Igbo.

The reverse situation, in which English verbs such as 'be supposed' and 'need' are used in the matrix clause, was also recorded. Such English verbs are inserted into the matrix clause and the Igbo verb in the complement clause appears in the infinitive form, as in (47) - (50):

(47) Ha suppose-ụi-rụ $\quad$ [CP ị-ma the hitches].

they be supposed-V-IND INF-know the hitches

'They are supposed to know the hitches.'

(48) A suppose-ụ̀-rụ̀ [CP i-nwe one month's training].

IMPERS. PN. be supposed-V-IND INF-have one month's training

'One is supposed to have one month's training.'

(49) E-need-ì-rì $m$ [i-de proposal $]$.

VOC-need-V-IND I INF-write proposal

'I need to write a proposal.'

(50) E-need-ì-rì $\mathrm{m}$ [ị-hụ gị].

VOC-need-V-IND I INF-see you

'I need to see you.' 
The Igbo verbs following the integrated forms of 'suppose' and 'need' in (47) through (50) appear in the infinitival form, just like the Igbo equivalents of the verbs would select English infinitive verbs, as illustrated above. This lends credence to the assumption that the selection and integration of English verbs in an Igbo clausal frame is indicative of an insertional pattern of codeswitching in which the matrix language dominates the clause.

It is interesting what is observed in cases in which the verb of the matrix clause and the verb of its clausal complement are both expressed in English, as in (51) and (52). In such cases, Igbo infinitival inflection is still required on the English verb in the complement clause.

(51) Government suppose-ụ-rụ [ị-upgrade the standard of public schools].

Government suppose-V-IND INF-upgrade the standard of public schools

'The government is supposed to upgrade the standard of public schools.'

(52) A-gà $\quad m$ è-need [i-move my people].

VOC-FUT I PRT-need INF-move my people

'I will need to move my people.'

The integration of the English verbs in the matrix clause and clausal complement in (51) and (52) is a good illustration of the Matrix-Embedded language dichotomy - both verbal expressions are insertions from the embedded language, and the Matrix Language, Igbo, supplies the grammatical frame and the system morphemes. Morphosyntactic integration of the English verbs results from the attachment of Matrix Language affixes to the verbs of the Embedded Language.

6.2. Morphosyntactic Integration in Structures Not Attested in English. In codeswitching involving languages that are typologically dissimilar, it is often possible to identify structures that clearly belong to one of the languages. In such structures, it is obvious when elements of one language have been inserted into the grammatical structure of the other language. In Igbo-English codeswitching, there are constructions that are attested in Igbo, but not in English. In such constructions, Igbo is clearly the Matrix Language. Examples are the bound cognate noun construction and the serial verb construction, which will be discussed in turn.

6.2.1. The bound cognate noun construction. The bound cognate noun is a nominal derivative of all active verbs in Igbo (Emenanjo, 1978, p. 133). The nominal is cognate with the verb root, and is formed from the verb root with a harmonizing $a$-le-prefix. The bound cognate noun follows the verb and its direct object/complement within the verb phrase, and "adds something extra to the meaning of the verb" (Emenanjo, 1978, p. 132), including emphasis, as the contrast between (53a) and the bound cognate noun construction in (53b) shows:

(53) a. O rì-rì nri nà.
s/he eat-PAST food this
'S/he ate this food.'

b. $\mathrm{O}$ rì-rì nri nà è-ri.

$\mathrm{s}$ /he eat-PAST food this HRM-eat $(\mathrm{BCN})$

'S/he actually ate this food.' 
Igbo-English bilinguals often insert English verbs into the Igbo bound cognate noun construction, as in the following examples:

(54) Zụ̂-ta-ra mànè̀ à̀ à̀ à-warm-ụ̀.

buy-ES-BNF me one IMPERS.PN. warm-V-PAST HRM-warm-V (BCN)

'Buy me one that has been warmed.'

(55) $\mathrm{O}$ nà- à-crack-ị à-crack-ị.

It PROG- PRT-crack-V HRM-crack-V (BCN)

'It's cracking.'

(56) À-rị-ghị

m ya elu. A-jump-ụ̀-rụ̀ m à-jump-ụ̀.

VOC-climb-NEG I it up. VOC-jump-V-PAST I HRM-jump-V (BCN)

'I did not climb it. I (actually) jumped.'

(57) $\grave{E}$
E
IMPERS.PN.
mix-ì-ghì tea ahụ
è-mix-ì.

'That tea was not mixed.'

(58) A

A gà- è-video ya è-video.

IMPERS.PN. FUT- PRT-video it HRM-video (BCN)

'It will be video-recorded.'

Examples (54) through (58) illustrate the fact that English verbs are treated exactly like Igbo verbs in the bound cognate noun construction - the English verb inserted in the verbal slot is inflected with Igbo affixes and a bound cognate noun derived from the English verb, using the regular derivational pattern for Igbo verbs, occurs at the end of the verb phrase.

6.2.2. The serial verb construction. The serial verb construction (SVC) is not a uniform type of linguistic construction in individual languages as well as across languages. The diversity of SVC types has made a general definition difficult. However, certain general features are shared by SVCs cross-linguistically. Aikhenvald (2006) captures the general characteristics in her description of SVCs as:

\begin{abstract}
a sequence of verbs which act together as a single predicate, without any overt marker of coordination, subordination, or syntactic dependency of any other sort. Serial verb constructions describe what is conceptualized as a single event. They are monoclausal; their intonational properties are the same as those of a monoverbal clause, and they have just one tense, aspect, and polarity value. SVCs may also share core and other arguments. [p. 1]
\end{abstract}

SVCs are common in Creole languages and languages of West Africa, Southeast Asia, Amazonia, Oceania, and New Guinea (Aikhenvald, 2006). In West Africa, they are found in the Benue-Congo, Kwa and Kru languages of Niger-Congo (Heine \& Nurse, 2000), extending as far as the Plateau languages of Central Nigeria and the Bantoid languages of the Grassfields of Cameroon (Kießling, 2004). Although SVCs are found in perhaps one-third of the languages of 
the world, they seem not to occur in Europe or north or central Asia, and are rather few in North America or Australia (Dixon, 2006).

Unlike coordination and subordination which are common to both Igbo and English, verb serialization is attested in Igbo but not in English. SVCs are used to express a wide range of semantic notions in Igbo, including comparison, instrument, manner, accompaniment, direction, dative, simultaneity, purpose, sequence and result (Amaechi, 2013; Emenanjo, 1978). Bamgbose (1982) identified four types of SVCs in the literature - the co-ordinate or linking SVC (or symmetrical SVC (Aikhenvald, 2006)), the modifying SVC (or asymmetrical SVC (Aikhenvald, 2006)), the purpose SVC and the complex SVC ((or one-word SVC (Aikhenvald, 2006)). Three of these SVC types have been identified in Igbo (Anyanwu, 2009), as exemplified below.

(59) $\mathrm{O}$ bù abọ ga-a ahịa.

s/he carry basket go-OVS market

'S/he went to the market with a basket.'

(60) $\mathrm{O}$ bịà-rà ri-e nri.

$\mathrm{s} /$ he come-PAST eat-OVS food

'S/he came to eat/for the purpose of eating.'

(61) Ọ kụ̀-wà-rà ìtè ahụ̀.

s/he hit-split-PAST pot that

'S/he broke that pot.' (lit: hit-split that pot) (Anyanwu, 2009, pp. 112-114).

The above examples illustrate the co-ordinate, purpose, and complex SVC, respectively. In the Igbo-English data for this study, the co-ordinate SVC (e.g. (62) and (63)), the modifying SVC (e.g. (64) and (65)) and the purpose SVC (e.g. (66)) were attested. However, a bilingual complex SVC, with verbs from the two participating languages merging to form one semantic unit and one phonological word, was not observed.

Lamidi (2009) has noted certain restrictions in serial verb constructions in Yoruba-English codeswitching. An examination of the SVC in Igbo-English codeswitching suggests that some restrictions apply in the construction. The following are examples:

(62) Kà $m$ ga ease-ì-e ònwe $m$.

let me go ease-V-OVS self my

'Let me go and ease myself.'

(63) A-gà ì è-depụ̀ta òfu akwụkwọ publish-ì-e.

VOC-FUT I PRT-write one paper publish-V-OVS

'I will write one paper and publish it.'

(64) $M$ jì nwayọ̀ na- è-build up my thesis.

I use gentleness PROG- PRT-build up my thesis

'I am gradually building up my thesis.' 
(65) Otu à kà ọ̀ sì end-ì-e. manner thisFOC it go from end-V-OVS 'That is how it ended.'

(66) I gà- à-bịa present-ì-e ya. you FUT PRT-come present-V-OVS it 'You will come to present it/for the purpose of presenting it.'

The examples (62) through (66) suggest a strict ordering of verbs in codeswitched serial verb structures - a general tendency for Igbo to provide the initial verb in the serial construction. Note, however, that this may just be a tendency and not an absolute requirement, and may apply to certain SVC types and not to others. More data would be required for a definite conclusion. The contrast between (67a) and (67b) below further lends credence to the assumption that switching of verbs in the SVC is generally from Igbo to English. The utterance in (67a) was recorded in actual speech, whilst the hypothetical (67b), in which the initial verb is in English, was adjudged by respondents as unacceptable, or to be minimally acceptable if used within the context of creating humour.
a. A-gà m à-ga check-ì-e ya. VOC-FUT I PRT-go check-V-OVS it
'I will go (and) check it.'
b. *I will go (and) hà-a ya.
I will go and check-OVS it
'I will go (and) check it.'

The ungrammaticality of (67b) strongly suggests that the matrix language provides the first of the serial verbs. An initial English clause, as in (67b) would require a following conjunction, thereby creating a coordinate clausal structure. No case was found, in the corpus, of an English verb as the first of serial verbs and an Igbo verb as second. In the only recorded example of an English verb as the first of serial verbs, the second verb is an English verb in a 'bilingual complex verb'/'doconstruction' (Muysken, 2000; Myers-Scotton, 2002).
(68) Postgraduate Board gà- è-meet-ì me-e ya approve.
postgraduate board FUT- PRT-meet-V do-OVS it approve
'The Postgraduate Board will meet and approve it.'

Note the morphological integration of the English verb meet in (68), as well as syntactic integration (marked by the absence of a determiner) in the subject noun phrase, suggestive of an overall Igbo morphosyntactic frame. 


\section{Distinguishing Alternation and Insertion in Peripheral Switching}

It is sometimes difficult to classify individual switches unambiguously as belonging to a specific codeswitching pattern (Deuchar, Muysken \& Wang, 2007; Muysken, 2000). A case in point is whether a switch from a subject in Language A to a verb phrase in Language B is a case of alternation, subject insertion or VP insertion (Muysken, 1995, 2000). This poses a problem to the analysis of some examples above as insertions on the basis of morphosyntactic integration. The question is: does Igbo-English alternational codeswitching never result in morphosyntactic integration of English verbs under any circumstances? The uncertainty of the situation is strengthened by the observation that alternation is a possibility when the switched element is at the periphery of a clause (Muysken, 1995, 2000). Therefore, it needs to be determined when a switch from the subject in one language into the verb phrase in the other language in Igbo-English codeswitching constitutes alternation, and when, insertion, especially in clause-peripheral switching.

In the examples of (clause-peripheral) alternational codeswitching cited in (16) through (22), the switch points are not between the subject and the verb phrase. However, those examples share two features with (69) and (70), in which the switch point is between a subject in one language and a verb phrase in another, namely, clause-peripheral switching and the occurrence of only monolingual verbs.

(69) Ndị be anyị have lived in peace for several decades now.

people place our have lived in peace for several decades now

'Our people have lived in peace for several decades now.'

(70) The thing gà na- à- ga-gharị.

the thing FUT PROG PRT- go-ES

'The thing will be going around/rotating.'

The switches in (69) and (70) represent true alternation. The clauses may be described in MLF terms as comprised of structural islands that are well formed in the grammars of the participating languages. Furthermore, neither Igbo nor English can be said to dominate the entire clause in terms of morphosyntactic structure or to serve as the matrix language. This is the distinguishing feature of alternational switching in this language pair, whatever the switch point in the clause none of the participating languages can be said to determine word order or to supply the system morphemes in the clause. However, clause-peripheral switching may not yield structural islands, as in the following examples:

(71) Ànyị nà- a-complain about what the government is doing.

we PROG PRT-complain about what the government is doing

'We are complaining about what the government is doing.'

(72) Ha sị $[\mathrm{CP}$ nà ha gà- à-support-ụ President $]$.

they say that they FUT PRT-support-V president

'They said that they will support the President.' 
In the examples (71) and the bracketed CP in (72) switching is from one language to the other but the switching results in mixed/bilingual constituents and not islands. The English verbs are preceded by Igbo auxiliary verbs and are inflected with Igbo participial prefixes. The same pattern of verbal integration is observable in (73) and (74) below, but there are no matrix language auxiliary verbs.

(73) Onye mụ-rụ ya e-play-ị-ghị his or her role.

person bear-IND him PFX-play-V-NEG his or her role

'His parent (lit. the person that bore him) did not play his or her role.'

(74) $\mathrm{O}$ reduce-ù-rù the price.

$\mathrm{s} / \mathrm{he}$ reduce-V-PAST the price

'S/he reduced the price.'

The examples (73) and (74) are mixed constituents. Igbo is the matrix language that provides the system morphemes that yield the integrated English verbs. The two examples contrast significantly with (69) and (70), in which there is no matrix language. The morphosyntactic integration of English verbs distinguishes the two sets of configuration. It is observed that only monolingual English verbs can occur in the type of configuration represented by (69) and (70), and only bilingual verbs can occur in the type of configuration represented by (73) and (74). The morphosyntactic structure in (73) and (74) can, therefore, be assumed to be an insertional structure, while (69) and (70) represent alternation. Thus, in Igbo-English codeswitching, the feature of morphological integration distinguishes clause-peripheral insertional and alternational switching between a subject in one language and a verb phrase in another.

The significance of verbal integration for insertional codeswitching is that the inflection on the verb determines the matrix language of the clause, even when both the subject and verb phrase positions are filled with English material. Consider (75) and (76):

(75) Some batteriesà-run-ụ̀-go down.

some batteries PFX-run-V-PERF down

'Some batteries have run down.'

(76) The government then nà- à-sponsor ndị inspectors.

the government then HAB- PRT-sponsor PL inspectors

'The government then (always) sponsored inspectors.'

The clauses in (75) and (76) appear to be English clauses with Igbo material inserted, but they are actually mixed constituents framed in Igbo (which supplies the system morphemes) into which English material has been inserted. The examples (71) through (76) indicate that morphological integration of English verbs can be predicted to occur whenever the morphosyntactic frame (and therefore the verbal inflection) is in Igbo, irrespective of what language supplies the material in the subject and verb phrase positions.

From the foregoing, it can be surmised that in Igbo-English codeswitching, the feature of morphosyntactic integration is related to the distinction between insertional codeswitching, in which Igbo is the matrix language in the clause, and alternational switching, in which the clause as 
a whole is not dominated by either language. Monolingual verbs indicate alternation, while an Igbo morphosyntactic frame produces verbal integration in an insertional pattern of codeswitching. Thus, verbal integration is the diagnostic feature of insertional codeswitching in Igbo-English codeswitching.

It is also observed that insertion is the dominant pattern in Igbo-English codeswitching. Evidence for this comes from the pervasiveness of morphologically integrated English verbs in the Igbo-English data. Further evidence comes from the directionality of switching. For example, Ahukanna (1991, p. 182) notes that "it is usually Igbo language based speech events that are flooded with English words and expressions and not the other way round." His description of the directionality of switching in this language pair corresponds to the observation in Deuchar, Muysken \& Wang (2007) and Muysken (2000) that the insertional pattern of codeswitching is unidirectional with an obvious matrix language, while alternation and congruent lexicalization are bidirectional.

\section{Conclusion}

The description of the structural patterns of Igbo-English intrasentential codeswitching given in the study identified two patterns of codeswitching, namely insertion and alternation. The patterns have distinctive structural characteristics. The alternational pattern involves a true switch from one language to the other and the clause as a whole is not dominated by either language in terms of the overall morphosyntactic structure. In the insertional pattern, there is asymmetry in the participation of the languages in the clause. The matrix language determines the word order of the clause and supplies the system morphemes, and elements of the embedded language (single words or phrases) are inserted into the structure framed in the matrix language. Igbo was shown to be the matrix language in the insertional pattern.

The study distinguishes the two codeswitching patterns by the feature of morphosyntactic integration, the diagnostic feature of the insertional pattern. The importance of this feature to the structuring of codeswitching in the language pair was established and amply illustrated. In uncertain contexts especially, such as clause-peripheral switching in which the subject and verb phrase are filled with material from both languages or from only English, verbal integration was shown to determine the status of such switching.

The study corroborates the claim that different codeswitching patterns may be realized in the same data set, but one pattern would usually dominate. In Igbo-English codeswitching, insertion was identified as the dominant pattern of codeswitching. The prevalence of the insertional pattern in Igbo-English codeswitching is related to the sociolinguistic context in Nigeria, the prestige status and superior roles enjoyed by the English language (as official language) vis-à-vis the indigenous languages. Igbo is one of the indigenous languages recognized as national languages (the other two are Hausa and Yoruba) but codeswitching among Igbo bilinguals and multilinguals is usually with the prestige language and not with other indigenous languages. The process of codeswitching in the Igbo-English language pair generally involves the insertion of linguistic material from the 'prestige language' into clausal structures framed in Igbo. 


\section{Abbreviations Used}

\begin{tabular}{|l|l|l|l|}
\hline$*$ & unattested/unacceptable & NEG & negative suffix \\
\hline APPL & applicative suffix & OVS & open vowel suffix \\
\hline BCN & bound cognate noun & PAST & past tense \\
\hline BNF & benefactive affix & PERF & perfective \\
\hline ES & extensional suffix & PFX & $\begin{array}{l}\text { verbal prefix used in certain } \\
\text { tenses with noun (phrase) or } \\
\text { plural pronoun subject }\end{array}$ \\
\hline FOC & focus & PL & plural \\
\hline FUT & future & PREP & preposition \\
\hline HAB & habitual & PRES & present \\
\hline HRM & harmony vowel & PROG & progressive aspect \\
\hline IMPERS.PN. & impersonal pronoun & PRT & participle prefix \\
\hline IND & indicative suffix & V & syllable structure vowel \\
\hline INF & infinitive marker & VOC & $\begin{array}{l}\text { vocative part of a } \\
\text { discontinuous } \\
\text { pronoun }\end{array}$ \\
\hline
\end{tabular}

\section{References}

Ahukanna, J. G. W. 1990. Bilingualism and code-mixing in language use in Nigeria: The case of Igbo-English bilinguals. In E. Nolue Emenanjo (ed.), Multilingualism, minority languages and language policy in Nigeria, 175-291. Agbor, Nigeria: Central Books.

Aikhenvald, Alexandra Y. 2006. Serial verb constructions in typological perspective. In Alexandra Y. Aikhenvald and R. M. W. Dixon (eds.), Serial verb constructions: A cross-linguistic typology, 1-68. Oxford: Oxford University Press.

Amaechi, Mary. 2013. Case Checking in Igbo Serial Verb Constructions. Research on Humanities and Social Sciences 3(9). 155-164.

Anyanwu, Rose-Juliet. 2009. On the strategic partnership of verbs: Serial verbs in Niger-Congo languages. In Matthias Brenzinger \& Anne-Maria Fehn (eds.), Proceedings of the 6th World Congress of African Linguistics Cologne, 17-21 August 2009, 107-119. Cologne: Rüdiger Köppe Verlag.

Auer, Peter. 1999. From codeswitching via language mixing to fused lects: Toward a dynamic typology of bilingual speech. International Journal of Bilingualism 3(4). 309-332.

Azuonye, Chukwuma. 2003. Igbo as an endangered language. Uwa Ndi Igbo: Journal of Igbo Life and Culture 3. 40-68. 
Backus, Ad. 2010. The role of codeswitching, loan translation and interference in the emergence of an immigrant variety of Turkish. Working Papers in Corpus-based Linguistics and Language Education 5. 225-241.

Bamgboșe, Ayọ. 1982. Issues in the analysis of serial verbal constructions. Journal of West African Languages 12(2). 3-21.

Baugh, John. 1993. Adapting dialectology: The conduct of community studies. In Dennis Preston (ed.), American dialect research, 167-191. Amsterdam: John Benjamins.

Bentahila, Abdelâli \& Eirlys. E. Davies. 1983. The syntax of Arabic-French code-switching. Lingua 59. 301-330.

Bentahila, Abdelâli \& Eirlys. E. Davies. 1998. Codeswitching: An unequal partnership? In Rodolfo Jacobson (ed.), Codeswitching worldwide, 25-49. Berlin: Mouton.

Bokamba, Eyamba G. 1989. Are there syntactic constraints on code-mixing? World Englishes 8(3). 277-292.

Deuchar, Margaret, Pieter Muysken \& Sung-Lan Wang. 2007. Structured variation in codeswitching: Towards an empirically based typology of bilingual speech patterns. The International Journal of Bilingual Education and Bilingualism 10(3). 298-340.

Dixon, R. M. W. 2006. Serial verb constructions: Conspectus and coda. In Alexandra Y. Aikhenvald \& R. M. W. Dixon (eds.), Serial verb constructions: A cross-linguistic typology, 338-350. Oxford: Oxford University Press.

Emenanjo, E. Nolue. 1978. Elements of modern Igbo grammar: A descriptive approach. Ibadan: Oxford University Press.

Emenanjo, E. Nolue. 2015. A grammar of contemporary Igbo: Constituents, features and processes. Port Harcourt: M \& J Grand Orbit Communications Ltd.

Eze, Ejike. 1998. Lending credence to a borrowing analysis: Lone English-origin incorporations in Igbo discourse. International Journal of Bilingualism 2(2). 183-201.

Gardner-Chloros, Penelope \& Malcolm Edwards. 2004. Assumptions behind grammatical approaches to code-switching: When the blueprint is a red herring. Transactions of the Philological Society 102(1). 103-129.

Heine, Bernd \& Derek Nurse. 2000. African languages: An introduction. Cambridge: Cambridge University Press.

Kamwangamalu, Nkonko M. 1992. 'Mixers' and 'mixing': English across cultures. World Englishes 11(2/3). 173-181.

Kießling, Roland. 2004. "The giraffes burst throw emerge climb pass through roof of the hut": Verbal serialisation in the West Ring languages (Isu, Weh, Aghem). In Akinbiyi Akinlabi \& Oluseye Adesola (eds.), Proceedings of the 4th World Congress of African Linguistics New Brunswick 2003, 225-235. Cologne: Rüdiger Köppe Verlag.

Lamidi, M. T. 2009. Switch junctions in Yorùbá-English code-switching. California Linguistic Notes 34(1). http://www.english.fullerton.edu/ publications/... (14 July, 2013).

Lipski, John M. 1982. Spanish-English language switching in speech and literature: theories and models. Bilingual Review 9(9). 191-212.

Muysken, Pieter. 1995. Code-switching and grammatical theory. In Lesley Milroy \& Pieter Muysken (eds.), One speaker, two languages: Cross-disciplinary perspectives on codeswitching, 177-198. Cambridge: Cambridge University Press.

Muysken, Pieter. 2000. Bilingual speech: A typology of code-mixing. Cambridge: Cambridge University Press. 
Myers-Scotton, Carol. 1992. Comparing codeswitching and borrowing. In Carol M. Eastman (ed.), Codeswitching, 19-39. Clevedon: Multilingual Matters.

Myers-Scotton, Carol. 1997. Duelling languages: Grammatical structure in codeswitching $\left(2^{\text {nd }}\right.$ edn.). Oxford: Oxford University Press.

Myers-Scotton, Carol. 1998. Structural uniformities vs. community differences in codeswitching. In Rodolfo Jacobson (ed.), Codeswitching worldwide, 91-108. Berlin: Mouton.

Myers-Scotton, Carol. 2002. Contact linguistics: Bilingual encounters and grammatical outcomes. Oxford: Oxford University Press.

Myers-Scotton, Carol. 2006. Multiple voices: An introduction to bilingualism. Malden, MA: Blackwell Publishing.

Nartey, Jonas N. A. 1982. Code-switching, interference or faddism? Language use among educated Ghanaians. Anthropological Linguistics 24(2). 183-192.

Nwachukwu, P. Akụjụoobi. 1987. The argument structure of Igbo verbs. Lexicon Project Working Papers 18. Cambridge, MA: MIT Centre for Cognitive Science.

Nwoye, Onuigbo G. 2003. Code-switching as a conscious discourse strategy: Evidence from Igbo. Multilingua 12(4). 365-385.

Obiamalu, Greg O. \& David U. Mbagwu. 2008. Motivations for code-switching among IgboEnglish bilinguals: A linguistic and socio-psychological survey. Ogirisi: A New Journal of African Studies 5. 27-39.

Poplack, Shana. 1980. Sometimes I'll start a sentence in Spanish Y TERMINO EN ESPAÑOL: Toward a typology of code-switching. Linguistics 18. 581-618.

Poplack, Shana. 1993. Variation theory and language contact. In Dennis Preston (ed.), American dialect research, 251-286. Amsterdam: John Benjamins.

Poplack, Shana. 2004. Code-switching. In Ulrich Ammon, Norbert Dittmar, Klaus J. Mattheier \& Peter Trudgill (eds.), Sociolinguistics. An international handbook of the science of language (2nd ed.), 589-596. Berlin: Walter de Gruyter.

Poplack, Shana \& Marjory Meechan. 1998. Introduction. How languages fit together in codemixing. International Journal of Bilingualism 2(2). 127-138.

Poplack, Shana, David Sankoff \& Christopher Miller. 1988. The social correlates and linguistic processes of lexical borrowing and assimilation. Linguistics 26. 47-104.

Poplack, Shana, Susan Wheeler \& Anneli Westwood. 1989. Distinguishing language contact phenomena: Evidence from Finnish-English bilingualism. World Englishes 8(3). 89-406.

Uduma, Eke O. 2010. Linguistic features of code mixing and code-switching among the educated Igbo bilinguals. Journal of Arts and Contemporary Society, 2. 10-19.

Ihuọma I. Akinrẹmi

Department of Linguistics and Nigerian Languages

University of Jos, Nigeria

homaremi@gmail.com
Submitted: 4 May 15

Accepted 12 Nov 15

Revisions received: 30 Jan 16 